\title{
The uptake of nutrients from the small intestine of gnotobiotic and conventional chicks
}

\author{
BY H. YOKOTA* AND MARIE E. COATES \\ National Institute for Research in Dairying, Shinfield, Reading RG2 9AT
}

(Received 8 May 1981-Accepted 12 November 1981)

\begin{abstract}
1. Uptake of $\mathrm{L}-\left[2(\mathrm{n})-{ }^{3} \mathrm{H}\right]$ methionine and $3-\mathrm{O}-$ methyl[ $\left[{ }^{4} \mathrm{C}\right]-\mathrm{D}-$ glucose $(3 \mathrm{MG})$ from jejunal loops in vivo was investigated in germ-free (GF), gnotobiotic (GN) and conventional (CV) chicks aged between 2 and 4 weeks.

2. Body-weight gain was less, and intestine weight per unit length greater, in CV and GN birds than in corresponding GF birds.

3. Uptake of both nutrients was less in $\mathrm{CV}$ and $\mathrm{GN}$ birds when calculated per $\mathrm{g}$ intestinal tissue, but no difference was found between any of the groups when uptake was expressed per unit length of intestine.

4. Concentration of methionine in mesenteric and cardiac blood was higher, and amounts in the intestinal wall lower, in CV chicks than in corresponding samples from GF birds.

5. Concentration of $3 \mathrm{MG}$ in mesenteric blood was similar in both environments but it was higher in cardiac blood and lower in the gut wall of CV birds.

6. It was concluded that uptake of methionine and glucose is not impaired by the presence of micro-organisms in the gut.
\end{abstract}

The morphology of the gut of animals reared in a germ-free (GF) environment differs from that of their conventional (CV) counterparts. The differences are particularly marked in young chicks. In the $\mathrm{CV}$ bird the small intestinal wall is thicker, mainly because of an increase in connective tissue, the turnover of mucosal cells is more rapid and the microvilli are shorter (see review by Coates, 1980). It has been postulated that these modifications, brought about by the presence of a microflora, might impair the efficiency of the gut, particularly its absorptive capacity, which could account for the poorer growth that is consistently observed in CV compared with GF chicks. Studies in vitro with everted sacs of chick small intestine showed that transport of vitamins of the B complex and of glucose across the intestinal wall was more rapid in preparations from GF chicks than in those from their CV controls (Ford \& Coates, 1971). In the experiments now reported, two in vivo techniques were applied to investigate the uptake of methionine from the small intestine of gnotobiotic and $\mathrm{CV}$ chicks. Since some of the free methionine taken up from the lumen is directly incorporated into protein in the mucosal cells a comparative experiment was done with a metabolically-inert substance, 3-O-methyl glucose (3MG) which follows the same active transport system as glucose.

\section{MATERIALS AND METHODS}

\section{Chicks}

Rhode Island Red $\times$ Light Sussex crossbred chicks were all hatched GF in Gustafsson stainless steel isolators (Gustafsson, 1959) as described by Harrison \& Coates (1972). CV controls were obtained by dosing GF birds soon after hatching with $0.2 \mathrm{ml}$ of a suspension of droppings from chicks reared in CV quarters. In one experiment a group of birds was dosed with a suspension of a growth-depressing organism, Streptococcus faecium strain SY1, with or without a faecal filtrate (Fuller et al. 1979).

The birds were maintained on a practical chick mash containing $(\mathrm{g} / \mathrm{kg})$ : maize meal 378 ,

* Present address: Laboratory of Animal Nutrition, School of Agriculture, Nagoya University, Nagoya 464, Japan. 
barley meal 200 , defatted soya-bean meal 345 , dried grass meal 30 , bone meal 15 , limestone flour 10 , vitamin supplement 5 , maize oil $10, \mathrm{NaCl} 6 \cdot 72, \mathrm{MnSO}_{4} \cdot 4 \mathrm{H}_{2} \mathrm{O} 0 \cdot 28$. It was sterilized by gamma radiation at $5 \mathrm{Mrad}$.

Measurements of absorptive capacity were made during the fourth week of life in Expts 1,3 and 4 and in the third week in Expts 2 and 5.

\section{Surgical technique}

Before surgery the birds were fasted overnight but allowed access to drinking water. They were anaesthetized with an intramuscular injection of sodium pentobarbital $(60 \mathrm{mg} / \mathrm{kg}$ body-weight) and, where necessary, by inhalation of diethyl ether. All experiments were done on the jejunum, i.e. the segment of small intestine between the entry of the bile ducts and the yolk stalk.

Perfusion method. An incision was made in the right side of the abdomen and the segment of intestine was withdrawn and cut at both ends, taking care not to damage the mesenteric blood supply. The contents were washed out with warm physiological saline $(8 \cdot 5 \mathrm{~g} \mathrm{NaCl} / \mathrm{l})$. Glass cannulas were tied into both ends and connected to a perfusion apparatus similar to that described by Tasaki \& Takahashi (1964). The perfusion fluid, $40 \mathrm{ml} \mathrm{Krebs-Ringer}$ phosphate buffer at $\mathrm{pH} 7 \cdot 4$, was circulated by means of an air injector and was kept at $41^{\circ}$ by passing through a water-bath. The container was calibrated so that changes in volume during the course of an experiment could be measured. Perfusion lasted for $30 \mathrm{~min}$.

In vivo loop method. The segment of intestine was exposed and washed out as described previously, and a ligature was tied at the distal end. A blunt-ended needle was inserted in the proximal end and held in place with a ligature. The test material in a volume of 3 or $5 \mathrm{ml}$ was delivered into the intestinal sac by syringe, and as the needle was withdrawn the ligature was tied tightly. The loop of intestine was replaced inside the body cavity, the incision was covered with a damp pad and the bird was maintained in a lightly-anaesthetized condition for up to $20 \mathrm{~min}$. In the experiments in which blood samples were required a plastic cannula was inserted through the common mesenteric vein into the branch draining the jejunum. Samples were withdrawn at intervals throughout the experiment. Systemic blood was taken by heart puncture at the end.

At the end of the experimental period by either technique the bird was killed, the jejunum was removed and its contents were collected. It was held vertically extended by a $12 \mathrm{~g}$ weight for measurement of length, then slit open, rinsed in saline, blotted and weighed. In Expts 3 and 4 samples of 1-2 $\mathrm{g}$ intestinal tissue were taken for measurement of radioactivity.

\section{Test materials}

A $10 \mathrm{~mm}$ solution of L-methionine in Krebs Ringer phosphate buffer was used, with the addition of $\mathrm{L}-\left[2(\mathrm{n})-{ }^{3} \mathrm{H}\right]$ methionine to give a radioactive concentration of $2 \mu \mathrm{Ci} / \mathrm{ml}$ in the loop experiments and $0.002 \mu \mathrm{Ci} / \mathrm{ml}$ in the perfusion fluids.

In Expt 4 a $20 \mathrm{~mm}$ solution of 3-O-methyl-D-glucose was used in which 3-O-[14 $\mathrm{C}]$ methylD-glucose was included, giving a radioactive concentration of $0 \cdot 1 \mu \mathrm{Ci} / \mathrm{ml}$. Both isotopes were supplied by the Radiochemical Centre, Amersham.

In the loop experiments $4 \mathrm{mg}$ polyethylene glycol (molecular weight $4000 ; \mathrm{PEG}) / \mathrm{ml}$ was included as a non-absorbable marker to follow changes in volume during the experimental period.

\section{Analytical methods}

Uptake of methionine or $3 \mathrm{MG}$ was assessed by reduction in concentration of the perfusate or the fluid remaining in the loop. Adjustment was made for changes in volume found either by direct reading of the perfusion reservoir or by concentration of PEG.

PEG was measured by the turbidometric method of Smith (1958). 
Table 1. Effect of bile on uptake of methionine and water from perfused chick jejunum in vivo

(Mean values with standard errors for seven or eight chicks)

\begin{tabular}{|c|c|c|c|c|}
\hline \multirow{2}{*}{$\begin{array}{l}\text { Time of perfusion }(\min ) \ldots \\
\text { Addition of bile... }\end{array}$} & \multicolumn{2}{|c|}{15} & \multicolumn{2}{|c|}{30} \\
\hline & 0 & + & 0 & + \\
\hline Method of measurement & \multicolumn{4}{|c|}{ (a) Methionine uptake $(\mu \mathrm{mol} / \mathrm{mm})$} \\
\hline \multirow{2}{*}{$\begin{array}{l}\text { Chemical } \\
\text { Radiometric }\end{array}$} & $0.29 \pm 0.02$ & $0.28 \pm 0.01$ & $0.44 \pm 0.04$ & $0.45 \pm 0.02$ \\
\hline & $0.31 \pm 0.02$ & $0.30 \pm 0.02$ & $0.43 \pm 0.03$ & $0.44 \pm 0.03$ \\
\hline \multicolumn{5}{|c|}{ (b) Water uptake $(\mu \mathrm{l} / \mathrm{mm})$} \\
\hline PEG & $7 \cdot 0 \pm 1 \cdot 6$ & $6 \cdot 7 \pm 1.4$ & $8.5 \pm 2.3$ & $9 \cdot 5 \pm 1 \cdot 7$ \\
\hline
\end{tabular}

0 , Bile absent; + , bile present; PEG, polyethylene glycol, molecular weight 4000 .

Methionine was determined chemically by the colorimetric method of Csonka \& Denton (1946), or by measuring radioactivity. The intestinal segments were homogenized with 5 vol. trichloracetic acid (100 g/l; TLA) and centrifuged at $1800 \mathrm{~g}$ for $10 \mathrm{~min}$. Free methionine or $3 \mathrm{MG}$ were determined by counting $0.1 \mathrm{ml}$ supernatant fraction in $10 \mathrm{ml}$ liquid scintillant (Insta-gel; Packard Instrument Co Inc, Caversham, Berks). For measurement of bound methionine the precipitate was digested with $3.0 \mathrm{ml} 1 \mathrm{M}$-hyamine hydroxide in methanol at $55^{\circ}$ until clear and a portion mixed with $10 \mathrm{ml}$ Insta-gel. Radioactivity was measured using a Packard Tri-Carb Liquid-Scintillation Spectrometer, using the internal standard technique.

\section{Plan of experiments}

Expt 1 was an exploratory test on $\mathrm{CV}$ birds to ascertain that the methionine concentrations measured by radioactivity were comparable to those obtained chemically, and to investigate whether or not bile had any effect on uptake of methionine or water. Sixteen birds were treated by the perfusion technique, and $0.2 \mathrm{ml}$ bile from gall bladders of $\mathrm{CV}$ chicks was added to the perfusion fluid of half the birds; a similar number were examined by the loop method and half received $0.1 \mathrm{ml}$ bile into the loop.

In Expt 2 the uptake of methionine was investigated by perfusion of the jejunum of groups of eight GF and CV chicks, and gnotobiotic birds that had been dosed with a culture of Strep. faecium strain SY1 and a faecal filtrate.

The loop technique was used for three experiments. In Expt 3 the uptake of methionine, its concentration in the gut wall and its appearance in the blood of groups of between seven and ten GF and CV chicks were examined after periods of 10 and $20 \mathrm{~min}$. A similar study was made on $3 \mathrm{MG}$ in Expt 4. To ensure that the time periods were not so long as to obscure any differences between the two types of chicks, Expt 5 was done on groups of five GF and $\mathrm{CV}$ birds to measure uptake of methionine and $3 \mathrm{MG}$ after periods of 5 and $10 \mathrm{~min}$.

\section{Statistical treatment}

The significance of differences between values of GF and CV chicks was examined by Student's $t$ test.

\section{RESULTS}

From the results shown in Table 1 it was apparent that radioactivity measurements and chemical analysis gave similar values for methionine, and the radiometric method was used for the rest of the investigations. Inclusion of bile in the perfusate did not influence uptake of methionine or water. In the loop technique methionine uptake was similarly unaffected, 
Table 2. Uptake in 30 min of $\left[{ }^{3} \mathrm{H}\right]$ methionine from perfused segments of small intestine of germ-free $(G F)$ and conventional $(C V)$ chicks, and chicks $(G N)$ associated with Strep. faecium strain SYI and a faecal filtrate

(Mean values with their standard errors for groups of eight chicks)

\begin{tabular}{|c|c|c|c|c|c|c|}
\hline \multirow[t]{2}{*}{ Type of chick } & \multicolumn{2}{|c|}{ GF } & \multicolumn{2}{|c|}{$\mathrm{CV}$} & \multicolumn{2}{|c|}{ GN } \\
\hline & Mean & $\mathrm{SE}$ & Mean & SE & Mean & SE \\
\hline $\begin{array}{l}\text { Body-wt gain }(\mathrm{g}) \\
\text { Uptake: }\end{array}$ & $96 \cdot 0$ & 5.67 & $82 \cdot 5^{*}$ & 2.65 & $76.9 * *$ & 3.78 \\
\hline$\mu \mathrm{mol} / \mathrm{g}$ & $84 \cdot 9$ & $7 \cdot 80$ & $65 \cdot 5^{*}$ & $5 \cdot 0$ & $63 \cdot 0^{*}$ & $4 \cdot 3$ \\
\hline$\mu \mathrm{mol} / \mathrm{mm}$ & 0.68 & 0.07 & 0.59 & 0.02 & 0.57 & 0.04 \\
\hline Segment length (mm) & $186 \cdot 0$ & $9 \cdot 6$ & $179 \cdot 0$ & $5 \cdot 3$ & $202 \cdot 0$ & $5 \cdot 1$ \\
\hline Segment wt $(\mathrm{mg} / \mathrm{mm})$ & $8 \cdot 0$ & 0.33 & $9 \cdot 4^{*}$ & 0.60 & $9 \cdot 1$ & 0.34 \\
\hline
\end{tabular}

Significance of difference from GF value: ${ }^{*} P<0.05,{ }^{* *} P<0.01$.

Table 3. Uptake during $20 \mathrm{~min}$ of $\left[{ }^{3} \mathrm{H}\right]$ methionine from in vivo segments of small intestine of germ-free $(G F)$ and conventional ( $C V$ ) chicks at 3 weeks of age

(Mean values with their standard errors; numbers of birds in parentheses)

\begin{tabular}{|c|c|c|c|c|c|}
\hline & \multirow{3}{*}{$\begin{array}{l}\text { Period of } \\
\text { uptake } \\
\text { (min) }\end{array}$} & \multicolumn{4}{|c|}{ Type of chick } \\
\hline & & \multicolumn{2}{|r|}{ GF } & \multicolumn{2}{|c|}{$\mathrm{CV}$} \\
\hline & & Mean & SE & Mean & $\mathrm{SE}$ \\
\hline Body-wt gain (g) & - & 184.9 & $5 \cdot 7 \quad(15)$ & $151 \cdot 1$ & $3.8 \quad(18)$ \\
\hline Segment length $(\mathrm{mm})$ & - & $259 \cdot 0$ & $12.99 \quad(15)$ & $302 \cdot 0$ & 13.59 (18) \\
\hline Segment wt (mg/mm) & - & 7.8 & $0.4 \quad(15)$ & $10 \cdot 0^{* * *}$ & $0.2 \quad$ (18) \\
\hline \multicolumn{6}{|l|}{ Uptake: } \\
\hline$\mu \mathrm{mol} / \mathrm{g}$ & $\begin{array}{l}10 \\
20\end{array}$ & $\begin{array}{l}11 \cdot 19 \\
19 \cdot 47\end{array}$ & $\begin{array}{ll}2.23 & (8) \\
2.68 & (7)\end{array}$ & $\begin{array}{r}9 \cdot 88 \\
14 \cdot 48\end{array}$ & $\begin{array}{l}0.80 \quad(8) \\
0.48 \quad(10)\end{array}$ \\
\hline \multirow[t]{2}{*}{$\mu \mathrm{mol} / \mathrm{mm}$} & 10 & 0.086 & $0.015(8)$ & 0.095 & $0.008(8)$ \\
\hline & 20 & $0 \cdot 142$ & $0.016(7)$ & 0.149 & $0.008(10)$ \\
\hline \multicolumn{6}{|l|}{$\left[{ }^{3} \mathrm{H}\right]$ methionine $(\mu \mathrm{mol}):$} \\
\hline \multirow[t]{4}{*}{ Mesenteric blood (/ml) } & 5 & 1.7 & $0.65 \quad(8)$ & 1.53 & $0.06 \quad(7)$ \\
\hline & 10 & $1 \cdot 2$ & $0.45 \quad(8)$ & 1.35 & $0.22 \quad(8)$ \\
\hline & 15 & 0.48 & $0.09 \quad(7)$ & $0.80^{*}$ & $0 \cdot 12(10)$ \\
\hline & 20 & 0.41 & 0.09 (7) & $0.79 *$ & $0.16 \quad(10)$ \\
\hline \multirow[t]{2}{*}{ Cardiac blood $(/ \mathrm{ml})$} & 10 & $0 \cdot 14$ & 0.04 (7) & 0.21 & 0.03 (5) \\
\hline & 20 & 0.15 & $0.04(4) \dagger$ & 0.26 & $0.02(8)$ \\
\hline \multicolumn{6}{|l|}{ Intestinal tissue $(/ \mathrm{g})$} \\
\hline \multirow[t]{2}{*}{ Free } & 10 & $3 \cdot 10$ & $0.63 \quad(8)$ & $1 \cdot 39^{*}$ & $0.44 \quad(8)$ \\
\hline & 20 & 1.98 & $0.46 \quad(7)$ & $0.67^{*}$ & $0 \cdot 16 \quad(10)$ \\
\hline \multirow[t]{2}{*}{ Bound } & 10 & 0.051 & $0.004(8)$ & 0.038 & $0.014(8)$ \\
\hline & 20 & 0.056 & $0.009(7)$ & 0.047 & $0.009(10)$ \\
\hline \multicolumn{6}{|l|}{$\mathrm{nmol} / \mathrm{mm}$} \\
\hline \multirow{2}{*}{ Free } & 10 & $24 \cdot 21$ & $5 \cdot 16(8)$ & $13 \cdot 26$ & $3.85 \quad(8)$ \\
\hline & 20 & $15 \cdot 36$ & $3.45 \quad(7)$ & $6.94^{*}$ & $1.71 \quad(10)$ \\
\hline \multirow[t]{2}{*}{ Bound } & 10 & 0.41 & $0.05 \quad(8)$ & 0.37 & $0 \cdot 14$ (8) \\
\hline & 20 & $0 \cdot 42$ & $0.06 \quad(7)$ & 0.49 & $0.11 \quad(10)$ \\
\hline
\end{tabular}

Significance of difference from GF values: $* P<0.05$.

$\dagger$ Adequate samples were not obtained from all birds. 
Table 4. Uptake during $20 \mathrm{~min}$ of $3-O-$-methyl $\left[{ }^{14} \mathrm{C}\right] \mathrm{glucose}(3 M G)$ from in vivo segments of small intestine of germ-free $(G F)$ and conventional $(C V)$ chicks at 3 weeks of age

(Mean values with their standard errors; nos. of chicks in parentheses)

\begin{tabular}{|c|c|c|c|c|c|}
\hline & \multirow{3}{*}{$\begin{array}{l}\text { Period of } \\
\text { uptake } \\
\text { (min) }\end{array}$} & \multicolumn{4}{|c|}{ Type of chick } \\
\hline & & \multicolumn{2}{|r|}{ GF } & \multicolumn{2}{|c|}{$\mathrm{CV}$} \\
\hline & & Mean & $\mathbf{S E}$ & Mean & $\mathrm{SE}$ \\
\hline Body-wt gain (g) & - & $172 \cdot 0$ & $6.5 \quad(17)$ & $140 \cdot 0$ & $4.4 \quad(21)$ \\
\hline Segment length $(\mathrm{mm})$ & - & $270 \cdot 0$ & $11 \cdot 2$ & $270 \cdot 0$ & $10 \cdot 1 \quad(21)$ \\
\hline Segment wt $(\mathrm{mg} / \mathrm{mm})$ & - & 8.3 & $0.3 \quad(17)$ & $10 \cdot 7^{*}$ & $0.3 \quad(21)$ \\
\hline \multicolumn{6}{|l|}{ Uptake: } \\
\hline \multirow[t]{2}{*}{$\mathrm{mol} / \mathrm{g}$} & 10 & $15 \cdot 37$ & $0.85 \quad(8)$ & $12 \cdot 30$ & $1.79 \quad(10)$ \\
\hline & 20 & $28 \cdot 34$ & $2.29 \quad(9)$ & $25 \cdot 14$ & 1.49 (11) \\
\hline \multirow{2}{*}{$\mu \mathrm{mol} / \mathrm{mm}$} & 10 & $0 \cdot 134$ & $0.012(8)$ & 0.135 & $0.021(10)$ \\
\hline & 20 & 0.228 & $0.019(9)$ & 0.264 & 0.013 (11) \\
\hline \multirow{5}{*}{$\begin{array}{l}\text { 3MG }(\mu \mathrm{mol}) \text { in: } \\
\text { Mesenteric blood }(/ \mathrm{ml})\end{array}$} & & & & & \\
\hline & 5 & 0.283 & $0.063(8)$ & $0 \cdot 298$ & $0.053(10)$ \\
\hline & 10 & 0.302 & $0.073(8)$ & 0.281 & $0.045(10)$ \\
\hline & 15 & 0.321 & $0.060(8)$ & 0.275 & 0.045 (11) \\
\hline & 20 & 0.287 & $0.034(9)$ & 0.288 & $0.029(11)$ \\
\hline \multicolumn{6}{|l|}{ Cardiac blood $(/ \mathrm{ml})$} \\
\hline & 10 & 0.84 & $0.08 \quad(6) \dagger$ & $1 \cdot 10$ & $0.146(10)$ \\
\hline & 20 & $1 \cdot 22$ & 0.09 (9) & $1 \cdot 77^{*}$ & $0.240(10)$ \\
\hline \multirow{2}{*}{ Intestinal tissue: $(/ \mathrm{g})$} & 10 & $10 \cdot 2$ & $1.29(8)$ & $11 \cdot 2$ & $0.95(10)$ \\
\hline & 20 & $9 \cdot 7$ & $2 \cdot 17 \quad(9)$ & $6 \cdot 1$ & 0.86 (11) \\
\hline \multirow{2}{*}{$(/ \mathrm{mm})$} & 10 & 0.122 & $0.056(8)$ & $0 \cdot 104$ & $0.026(10)$ \\
\hline & 20 & $0 \cdot 127$ & $0.094(9)$ & $0.057^{*}$ & $0.022(11)$ \\
\hline
\end{tabular}

Significance of difference from GF value: $* P<0.05$.

$\dagger$ Adequate samples were not obtained from all birds.

the amounts $(\mu \mathrm{mol} / \mathrm{mm})$ taken up in $20 \mathrm{~min}$ being $0.0933 \pm 0.0035$ and $0.0926 \pm 0.0022$ without and with bile respectively. Results of the second perfusion experiments are given in Table 2. In comparison with GF birds, body-weight of the CV group was significantly depressed, and that of the group treated with Strep. faecium and filtrate even lower. The intestinal weight was increased in both. Uptake, calculated as $\mu \mathrm{mol}$ methionine taken up per $\mathrm{g}$ gut tissue, was significantly reduced in both the $\mathrm{CV}$ and mono-associated group, but because the intestinal wall was thicker in these groups the difference was not apparent when expressed per unit length of intestine.

The uptake of methionine from in vivo loops of jejunum and its appearance in the blood of GF and CV chicks is shown in Table 3. A similar pattern was observed, with decreased body-weight and increased intestinal weight in the CV birds. Uptake calculated in terms of weight of intestinal tissue was reduced (though not significantly) in the CV birds but no difference was found when calculated in terms of length. After $15 \mathrm{~min}$ the concentration of methionine in mesenteric blood of $\mathrm{CV}$ chicks was significantly higher and in systemic blood after $20 \mathrm{~min}$. Conversely, the amounts of free methionine in the intestinal wall were significantly higher in the GF birds, whether calculated in terms of weight or length. The amounts of bound methionine were not different in the two groups, but the ratio, bound: free was higher in the CV tissue (GF 0.016 and 0.028, CV 0.027 and 0.070 at 10 and $20 \mathrm{~min}$ respectively).

Table 4 records results of a similar experiment done with $3 \mathrm{MG}$. On this occason there were no significant differences in uptake, although after 20 min concentration in systemic 
Table 5. Uptake during $10 \mathrm{~min}$ of $\left[{ }^{3} \mathrm{H}\right]$ methionine or $3-\mathrm{O}$-methyl $\left[{ }^{14} \mathrm{C}\right] \mathrm{glucose}(3 \mathrm{MG})$ from in vivo segments of small intestine of germ-free $(G F)$ and conventional $(C V)$ chicks at 2 weeks of age

(Mean values with standard errors; nos. of chicks in parentheses)

\begin{tabular}{|c|c|c|c|c|c|c|c|}
\hline & \multirow{3}{*}{$\begin{array}{l}\text { Period of } \\
\text { uptake } \\
\text { (min) }\end{array}$} & \multicolumn{6}{|c|}{ Type of chick } \\
\hline & & \multicolumn{3}{|c|}{ GF } & \multicolumn{3}{|c|}{$\mathrm{CV}$} \\
\hline & & Mean & & SE & Mean & & $\mathrm{SE}$ \\
\hline \multirow[t]{2}{*}{ Body-wt gain (g) } & - & 94 & $5 \cdot 1$ & $(20) \dagger$ & $76^{* *}$ & 1.9 & $(20) \dagger$ \\
\hline & \multicolumn{4}{|c|}{ (a) $\left[{ }^{3} \mathrm{H}\right]$ methionine } & & & \\
\hline Segment length $(\mathrm{mm})$ & - & $298 \cdot 0$ & $7 \cdot 9$ & (10) & $313 \cdot 0$ & $8 \cdot 6$ & $(10)$ \\
\hline \multicolumn{8}{|l|}{ Uptake } \\
\hline \multirow[t]{3}{*}{$\mu \mathrm{mol} / \mathrm{g}$} & 5 & $9 \cdot 28$ & 0.53 & $(5)$ & $8 \cdot 28$ & 0.58 & (5) \\
\hline & 10 & $15 \cdot 29$ & 0.74 & (5) & $9 \cdot 75^{* * *}$ & 0.60 & (5) \\
\hline & 5 & 0.055 & 0.002 & $2(5)$ & 0.063 & 0.002 & $2(5)$ \\
\hline \multirow[t]{2}{*}{$\mu \mathrm{mol} / \mathrm{mm}$} & 10 & $0 \cdot 080$ & 0.003 & $3(5)$ & $0 \cdot 076$ & 0.002 & $2(5)$ \\
\hline & \multicolumn{4}{|c|}{ (b) $\left[{ }^{14} \mathrm{C}\right] 3 \mathrm{MG}$} & & & \\
\hline Segment length $(\mathrm{mm})$ & - & 324.0 & $7 \cdot 1$ & (9) & $301 \cdot 0$ & $12 \cdot 8$ & $(10)$ \\
\hline Segment wt $(\mathrm{mg} / \mathrm{mm})$ & - & $5 \cdot 5$ & $0 \cdot 1$ & (9) & $7 \cdot 9^{* * *}$ & $0 \cdot 3$ & $(10)$ \\
\hline \multicolumn{8}{|l|}{ Uptake } \\
\hline \multirow[t]{2}{*}{$\mu \mathrm{mol} / \mathrm{h}$} & 5 & $18 \cdot 50$ & $1 \cdot 24$ & (5) & $13 \cdot 73$ & $1 \cdot 35$ & $(5)$ \\
\hline & 10 & $26 \cdot 16$ & $1 \cdot 37$ & (4) & $18 \cdot 55^{* * *}$ & 0.65 & (5) \\
\hline \multirow[t]{2}{*}{$\mu \mathrm{mol} / \mathrm{mm}$} & 5 & 0.106 & 0.065 & $5(5)$ & $0 \cdot 106$ & 0.047 & $7(5)$ \\
\hline & 10 & $0 \cdot 138$ & 0.061 & (4) & $0 \cdot 147$ & 0.054 & $4(5)$ \\
\hline
\end{tabular}

Significance of difference from GF values: ** $P<0.01 ; * * * P<0.001$.

$\dagger$ Five birds were selected at random from the group of twenty for measurement of uptake of each compound at each time.

blood was higher in the CV group. At the same time less $3 \mathrm{MG}$ was found in the intestinal tissue of the CV birds. In Expt 5 (Table 5), when uptake was measured after 5 and $10 \mathrm{~min}$, it was apparently higher for both methionine and $3 \mathrm{MG}$ when calculated per $\mathrm{g}$ tissue, but not when expressed in terms of length.

\section{DISCUSSION}

Several techniques have been devised to measure aspects of absorption in vivo, but for most of them the confidence with which findings can be related to the situation in the intact live animal is open to some question. The two methods used in this work measured uptake of methionine from the lumen, that is, the combined effects of an active transport system and passive diffusion, so that any differences between germ-free and conventional birds in the proportions contributed by these two systems might have been masked. The initial concentration of methionine $(10 \mathrm{~mm})$ was that used in earlier studies of amino acid absorption in CV chickens (Yokoto \& Tasaki, 1970) and was estimated to be within the physiological range. The same initial concentration was used in both techniques, but the volume was 8-10 times greater in the perfusion experiment. In the loop method the concentration decreased rapidly to about one-sixth of the original value after $10 \mathrm{~min}$ (Table 3) whereas concentration of the perfusion fluid remained relatively more stable, retaining more than half its initial value after $30 \mathrm{~min}$, which no doubt accounts for the higher uptake recorded in the perfusion experiments. The fact that uptake by GF and CV birds was similar under these two conditions of concentration suggests that the contributions from 
active and passive transport systems in each type of chick were not widely different. However, more precise studies of absorption rates would be necessary to establish this.

It has been observed in several species of animal, using both in vitro and in vivo systems, that bile salts influence transport of nutrients including amino acids, sugars and water across the gut wall (Pope et al. 1966; Frizzell \& Schultz, 1970; Teem \& Phillips, 1972; Hajjar et al. 1975). Since gut micro-organisms are capable of modifying bile acids it seemed possible that differences in nutrient uptake between GF and CV birds might result from alterations in the composition of the bile acids. However, as an exploratory test in CV birds showed that the uptake of methionine was not affected by the addition of bile in either of the in vivo systems used, this aspect of the problem was not pursued further.

In all comparisons between $\mathrm{GF}$ and $\mathrm{CV}$ chicks the body-weight gain was significantly greater in the GF environment and the weight per unit length of gut segment was significantly less. The uptake by the intestinal segments expressed as the amount of methionine or $3 \mathrm{MG}$ that had left the lumen per $\mathrm{g}$ tissue was invariably less in the $\mathrm{CV}$ birds, the reduction being statistically significant in Expts 2 and 5. However, this effect was apparently a reflection of the thicker gut wall in the CV birds, since when uptake was expressed in terms of intestinal length there was no difference between birds from the two environments. It has been shown that the increased wall thickness in the intestine of CV birds is mainly due to an increase in connective tissue (Gordon \& Bruckner-Kardoss, 1961), which is not directly concerned with nutrient uptake. Thus length seems to be a more valid basis on which to compare uptake, particularly as the over-all length of the small intestine does not differ significantly between birds in the two environments (Coates \& Jayne-Williams, 1966). By this criterion it must be concluded that uptake of methionine or 3MG (and hence of glucose) was not impaired in CV birds, nor in birds associated with the growth-depressing combination of Strep. faecium and a faecal filtrate.

This conclusion is substantiated by the finding that concentrations of methionine of $3 \mathrm{MG}$ in mesenteric blood were no greater in GF than in CV samples. On the contrary, after $15 \mathrm{~min}$ methionine concentration was higher in mesenteric blood from CV birds and in their systemic blood after $20 \mathrm{~min}$. In spite of the thinner wall the intestinal tissue of GF chicks contained more methionine, even when calculated per unit length, than the corresponding $\mathrm{CV}$ tissue. It was mainly in the TCA-soluble fraction, but the proportion of radioactivity in the TCA-insoluble fraction, though small, was greater in the CV tissue. This is compatible with other findings (Muramatsu et al. 1981) that suggest a faster rate of protein synthesis in the gut of $\mathrm{CV}$ compared with GF birds. Absorption of $3 \mathrm{MG}$, which is not complicated by its involvement in metabolic processes in the gut wall, followed a roughly similar pattern to that of methionine. Although no differences in concentration in mesenteric blood were observed, cardiac blood from CV birds had a higher concentration of 3MG after 20 min than did corresponding samples from GF birds. At the same time the amount of radioactivity in the intestinal tissue was significantly less.

These results are not in accord with our earlier findings using everted sacs of intestine in vitro, in which glucose and several members of the vitamin B complex were transported from the mucosal to the serosal side in greater amounts in the GF preparation. In isolated sacs transport across the wall must depend to a large extent on diffusion, and it is perhaps not surprising that greater amounts of the vitamins passed across the thinner-walled intestine of GF chicks. More catabolism of glucose in the thicker wall of the loops from CV birds may have resulted in spuriously low serosal concentrations, an error avoided in the in vivo studies by the use of $3 \mathrm{MG}$. The findings in vivo suggest that there is little difference in uptake of glucose or methionine from the lumen but that passage of nutrients into the portal system and eventually into systemic blood is more rapid in the CV state. This might occur if there were a greater blood flow to the gut of $\mathrm{CV}$ birds, although unpublished work 
(M. F. Palmer, personal communication) suggests that the reverse is true. Clearly the results lend no support to the idea that impaired absorption is responsible for the poorer growth of CV compared with GF chicks, but it may be that slower removal of nutrients from the gut wall allows more efficient utilization or conservation, possibly by reducing concentration in renal blood and consequent urinary excretion.

The authors are grateful to Mr J. P. Fordham for care and management of the chicks and to Mrs Rosemarie Anderson and Mr S. J. Stell for technical assistance. HY was an exchange scientist between the Japan Society for the Promotion of Science and The Royal Society, supported by the former.

\section{REFERENCES}

Coates, M. E. (1980). In Growth in Animals, p. 175 [T. L. J. Lawrence, editor]. London-Boston: Butterworths. Coates, M. E. \& Jayne-Williams, D. J. (1966). In Physiology of the Domestic Fowl, p. 182 [C. Horton-Smith and E. C. Amoroso, editors]. Edinburgh and London: Oliver \& Boyd Ltd.

Csonka, F. A. \& Denton, C. A. (1946). J. biol. Chem. 163, 329.

Ford, D. J. \& Coates, M. E. (1971). Proc. Nutr. Soc. 30, $10 \mathrm{~A}$.

Frizzell, R. A. \& Schultz, S. G. (1970). Biochim. biophys. Acta 211, 589.

Fuller, R., Coates, M. E. \& Harrison, G. F. (1979). J. appl. Bact. 46, 335.

Gordon, H. A. \& Bruckner-Kardoss, E. (1961). Acta anat. 4, 210.

Gustafsson, B. E. (1959). Ann. NY Acad. Sci. 78, 17.

Haijar, J. J., Khuri, R. N. \& Bikhazi, A. B. (1975). Am. J. Physiol. 229, 518.

Harrison, G. F. \& Coates, M. E. (1972). Br. J. Nutr. 28, 213.

Muramatsu, T., Coates, M. E., Hewitt, D., Salter, D. N. \& Garlick, P. J. (1981). Proc. Nutr. Soc. 40, 15A.

Pope, J. L., Parkinson, T. M. \& Olson, J. A. (1966). Biochim. biophys. Acta 130, 218.

Smith, R. H. (1958). Nature, Lond. 182, 260.

Tasaki, I. \& Takahashi, N. (1964). J. Nutr. 88, 359.

Teem, M. V. \& Phillips, S. F. (1972). Gastroenterology 62, 261.

Yokota, H. \& Tasaki, I. (1970). Jap. J. Zootech, Sci. 41, 209. 